\title{
Primeiro relato do Tomato spotted wilt virus (TSWV) em Campanula medium L. no Brasil
}

\author{
Ricardo Gioria ${ }^{1}$, Kátia Regiane Brunelli ${ }^{1}$, Romulo Fujito Kobori ${ }^{1}$, Márcia Maria Rabelo Guimarães Kobori ${ }^{1}$, Jorge \\ Alberto Marques Rezende ${ }^{2}$, Elliot Watanabe Kitajima²
}

${ }^{1}$ Sakata Seed Sudamerica, C.P. 427, 12906-840, Bragança Paulista, SP, ${ }^{2}$ ESALQ/USP, Setor de Fitopatologia, C.P. 09, 13418-900, Piracicaba, SP. Autor para correspondência:Ricardo Gioria (ricardo.gioria@sakata.com.br)

Data de chegada: 30/04/2008. Aceito para publicação em: 10/02/2010.

\section{RESUMO}

Gioria, R.; Brunelli, K.R.; Kobori, R.F.; Kobori, M.M.R.G.; Rezende, J.A.M.; Kitajima, E.W. Primeiro relato do Tomato spotted wilt virus (TSWV) em Campanula medium L. no Brasil. Summa Phytopathologica, v.36, n.2, p.176-177, 2010.

Plantas de campânula (Campanula medium) exibindo mosaico e necrose foliar e anéis em flores foram coletadas em uma estufa comercial de flores na região de Atibaia, SP. Suspeitando de possível etiologia viral, amostras de tecido lesionado foram analisadas por ensaios de transmissão mecânica, microscopia eletrônica e sorologia. Todos os resultados apontaram para a presença do Tomato spotted wilt virus (TSWV) como o responsável pelos sintomas. Esse é o primeiro relato deste patógeno em campânula no Brasil.

Palavras-chave adicionais: Tospovírus; Campânula; Campanulaceae

\section{ABSTRACT}

Gioria, R.; Brunelli, K.R.; Kobori, R.F.; Kobori, M.M.R.G.; Rezende, J.A.M.; Kitajima, E.W. First report of Tomato spotted wilt virus (TSWV) infecting Campanula medium in Brazil. Summa Phytopathologica, v.36, n.2, p.176-177, 2010.

Plants of bellflower (Campanula medium) exhibiting symptoms of mosaic, leaf necrosis and flower ring spot were found in a commercial crop in a greenhouse in Atibaia, São Paulo State. Electron microscopy, serology and biological assays indicated the presence of Tomato spotted wilt virus (TSWV). This is the first report of this pathogen in bellflower plants in Brazil.

Keywords: Tospovirus; Bellflower; Campanulaceae

Recentemente introduzida no Brasil como mais uma opção para os produtores de plantas ornamentais, a campânula (Campanula medium L.) tem sua demanda no mercado consumidor em franca expansão. Com o aumento nas áreas cultivadas os problemas fitossanitários vêm se tornando importantes entraves para o cultivo desta ornamental. Em dezembro de 2007 cinco plantas de campânula cv. Champion, exibindo sintomas de mosaico e necrose foliar e anéis e manchas nas flores (figura 1a e 1b) foram observadas em uma estufa produtora de flores na região de Atibaia, SP. Suspeitando de etiologia viral, tecido das plantas afetadas foram analisados em microscópio eletrônico de transmissão e submetidos a testes sorológicos. Extratos foliares das mesmas plantas foram inoculados para indexação biológica em espécies indicadoras. Exames de secções ultrafinas de tecido foliar de campânula e de plantas-teste de Nicotiana tabacum cv. Xanthi sintomáticas revelaram a presença de efeitos citopáticos característicos de tospovirus (partículas circulares ou elípticas com aproximadamente $80 \mathrm{~nm}$ de diâmetro contidas em cavidades do retículo endoplasmático e massas densas no citoplasma) (4) (Figura 1c e 1d). Extratos de tecido floral sintomático foram submetidos a teste de PTA-ELISA (5) com antisoros contra o Tomato spotted wilt virus (TSWV), Tomato chorotic spot virus (TCSV), Groundnut ringspot virus (GRSV) e Zucchini lethal chlorosis virus (ZLCV) gentilmente cedidos pelo Dr. A. C. de Ávila, Embrapa, Brasília. Houve reação positiva apenas para o anti-soro contra o TSWV (dados não apresentados). A reação de diversas espécies de plantas-teste mecanicamente inoculadas com

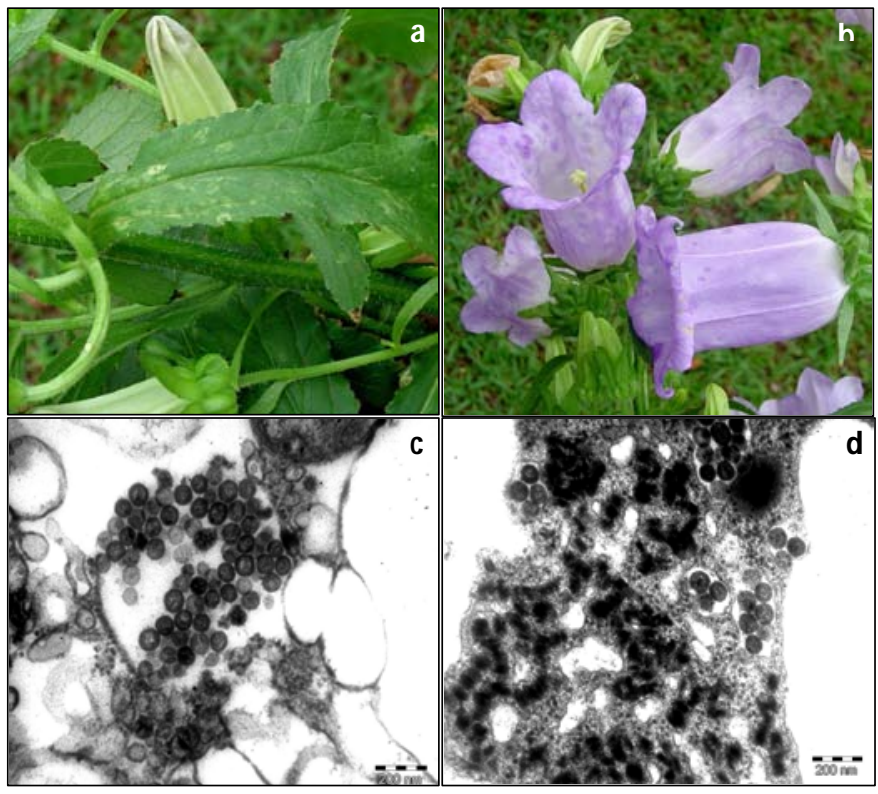

Figura 1. Campânula infectada com o Tomato spotted wilt virus (TSWV) exibindo sintomas de mosaico foliar (a) e anéis nas flores (b). Partículas virais circulares presentes nas cavidades do retículo citoplasmático em tecido foliar de campânula infectada naturalmente pelo TSWV (c) e de Nicotiana tabacum cv. Xanthi inoculada mecanicamente com o mesmo isolado $\operatorname{viral}(\mathrm{d})$. 
Tabela 1. Reação de diferentes espécies vegetais inoculadas mecanicamente com extrato de folhas de campânula exibindo sintomas de mosaico e necrose.

\begin{tabular}{|c|c|c|}
\hline \multicolumn{2}{|r|}{ Plantas-teste } & \multirow[t]{2}{*}{ Sintomas* } \\
\hline Família & Espécie & \\
\hline \multicolumn{3}{|c|}{ Asteraceae } \\
\hline & Lactucae sativa cv. Elisa & $\mathrm{M} / \mathrm{N}$ \\
\hline \multicolumn{3}{|c|}{ Campanulaceae } \\
\hline & Campanula medium & $\mathrm{M} / \mathrm{N} / \mathrm{A}$ \\
\hline \multicolumn{3}{|c|}{ Chenopodiaceae } \\
\hline & Chenopodium quinoa & LLN \\
\hline \multicolumn{3}{|c|}{ Cucurbitaceae } \\
\hline & Cucurbita pepo cv. Caserta & AS \\
\hline & Cucumis melo cv. Amarelo CAC & AS \\
\hline \multicolumn{3}{|c|}{ Portulacaceae } \\
\hline & Portulaca oleraceae & LLC \\
\hline \multicolumn{3}{|c|}{ Solanaceae } \\
\hline & Datura metel & LLN/M \\
\hline & D. stramonium & LLN/M \\
\hline & Capsicum chinense PI 159236 & AS \\
\hline & C. annuит cv. Magda & $\mathrm{M} / \mathrm{N} / \mathrm{A}$ \\
\hline & Nicotiana glutinosa & LLN \\
\hline & N. rustica & $\mathrm{M} / \mathrm{A}$ \\
\hline & N. tabacum cv. Xanthi & $\mathrm{M} / \mathrm{A}$ \\
\hline & Lycopsersicon esculentum cv. Santa Clara & $\mathrm{M} / \mathrm{N}$ \\
\hline & Petunia hibrida & LLN \\
\hline
\end{tabular}

* (A) Anéis; (AS) Ausência de sintomas; (LLC) Lesão local clorótica; (LLN) Lesão local necrótica; (M) Mosaico; (N) Necrose extrato foliar obtido em tampão fosfato de potássio $0,02 \mathrm{M}, \mathrm{pH}$ 7,0 , contendo sulfito de sódio $0,02 \mathrm{M}$, diluído $1: 10(\mathrm{p} / \mathrm{v})$ está apresentada na tabela 1 . A ausência de sintomas na pimenta PI 159236 corrobora o resultado do teste serológico que indica a infecção pelo TSWV, visto que esta possui o gene $T s w$ que confere resistência apenas a esta espécie do gênero Tospovirus $(1,2,3)$. A infecção de espécies do gênero Campanula ao TSWV (C. americana; C. glomerata; C. isophylla; C. latiloba; C. persicifolia; $C$. pyramidalis e $C$. rapuncupoides) já foi constatada em outros países (6), porém a presença deste vírus na espécie $C$. medium não se acha ainda descrita. No Brasil este é o primeiro relato do TSWV nesta ornamental.

\section{REFERÊNCIAS BIBLIOGRÁFICAS}

1. Black, L.L.; Hobbs, H.A.; Qatti, J. M. Jr. Tomato spotted wilt virus resistance in Capsicum chinense PI 152225 and PI 159236. Plant Disease, St. Paul, v.75, p. 863, 1991.

2. Boiteux, L.S. Allelic relationships between genes for resistance to Tomato spotted wilt tospovirus in Capsicum chilense. Theorical and Applied of Genetics, Berlin, v.90, p.146-149, 1995.

3. Boiteux, L.S.; de Ávila, A.C. Inheritance of a resistance specific to tomato spotted wilt tospovirus in Capsicum chinense 'PI 159236'. Euphytica, v.75, Holanda, p.139-142, 1994.

4. Kitajima, E.W.; de Ávila, A.C.; Resende, R.O.; Goldbach, R.W.; Peters, D. Comparative cytological and immunogold labeling studies on different isolates of tomato spotted wilt virus. Journal Submicroscopic Cytology and Pathology, v.24, p. 1-14, 1992.

5. Mowat, W.P.; Dawson, S. Detection of plant viruses by ELISA using crude sap extracts unfractioned antisera. Journal of Virological Methods, Holanda, v.15, p.233-247, 1987.

6. Parrella, G.; Gognalons, P.; Gebre-selassie K.; Vovlas, C.; Marchoux, G. An update of the host range of Tomato spotted wilt virus. Journal of Plant Pathology, Bari, v.85, p. 227-264, 2003. 